\title{
The cultivation model of transformation in the newly-built universities in developing training mode
}

\author{
Shuxian Huang ${ }^{1, a}$ \\ ${ }^{1}$ Jiangxi Institute of Fashion Technology, Jiangxi, Nanchang, 330201 \\ a362112768@qq.com
}

Keywords: Newly built undergraduate course; Colleges and universities transformation; Talent training mode; To discuss

\begin{abstract}
With the rapid development of education undertakings, the newly built undergraduate course colleges and universities in the aspect of education also gradually transition. Its not only in terms of talent cultivation with new requirements. And on the talent training mode also change. So, in order to be able to let the newly built undergraduate course colleges and universities to cultivate more excellent talents, is very key to the personnel training mode is studied. This article mainly aimed at the newly built undergraduate course colleges and universities transformation in developing training mode are discussed in this paper, and put forward the corresponding optimization strategy.
\end{abstract}

\section{The introduction}

With the transformation of the pattern of economic development, transformation and upgrading of industrial structure, the country is a massive increase in demand for high-quality talents in the field of technical skills, and the newly built local undergraduate colleges and universities and the synchronous development of traditional universities and colleges of undergraduate course, the talent training "underemployed", "excessive education" problem. In the face of China's economic and social development of the new requirement and expectation of higher education, a new local undergraduate colleges and universities should be based on popularization of higher education, the transformation development application technology university, this is a necessary choice to cope with the new situation. But in the actual teaching process, it still will appear all sorts of problems in teaching. So, to the transformation of colleges and universities in developing discusses the talents cultivation model is the key.

\section{Transformation of developing talent training newly built undergraduate course colleges and universities}

Transformation of newly built undergraduate course colleges and universities personnel training present situation. In the newly built undergraduate course colleges and universities, the personnel training mode also has certain defects. Especially in some private colleges, although is committed to the development of the applied university, in many cases, but many problems still occur. Many colleges and universities are for-profit, on the teaching quality and didn't do a lot of investment in equipment, so that students learn the practical knowledge is also apparent. Students at the time of entering the society, widespread delinked theoretical knowledge and practical operation. So, a lot of graduates often means when graduation unemployed. So, stand in the perspective of subjective analysis, newly built undergraduate course colleges and universities in the transformation of talented person's raise still exist a lot of defects. But from the overall trend, some colleges and universities will also be a lot of money to invest in construction. So, as long as the improvement of the personnel training system to conduct a comprehensive, then the newly-founded must be able to train a large number of talented people.

The significance of transformation of newly built undergraduate course colleges and universities personnel training. Transformation of talents cultivation can not only deepen the comprehensive reform of education system, also can promote the newly-built local undergraduate colleges and universities to develop in the university of applied technology transformation. So, in 
the process of the training, can let the practice ability of students get the comprehensive enhancement. And teachers in the teaching process, according to some actual situation, let the students do some academic report regularly, strengthening the practical training at the same time, for application-oriented university undergraduates to become excellent laid the deep foundation.

\section{Newly built undergraduate course colleges and universities of applied talents training mode in the existing main problems}

We need to do is the unity of the development of economy and undergraduate talent is. Also want to have a fixed on the cultivation of the talent structure and mode, in order to more effectively the cultivation of college talents. Many current university is also based on their experience to reform, so as to explore the way of talent training, and it has made a lot of satisfactory results. Will tell from the results, we still need to go in the way of exploring, which is helpful for us to solve more problems.

Newly-built local undergraduate colleges and universities in the misunderstanding between the ways of running. Most of the undergraduate course colleges and universities are now popular education model. Without a good breakthrough in terms of talent cultivation. New place regular undergraduate education accounted for the proportion of is more and more high. Because now a lot of colleges and universities by the impact of the economic benefits, and the influence of social commentary, of our school, is the root of the deviation from the school. Public opinion made the operators did not have the direction. In this case, colleges and universities in the use of resources, unreasonable distribution, there is no sufficient utilization of resources, since the cultivated talents, not good combining theory and practice of full up. That doesn't get social recognition, give play to the role of is not their own, make self values.

Courses in set is not reasonable enough. Practice ability in the teaching material management ability is weak, and is the lack of a more scientific appraisal mechanism. Due to the deep-rooted tradition education, and simplification, makes a lot of application-oriented undergraduate course colleges and universities even in culture teaching contents, and curricular system, and real teaching. Series of reforms were carried out. So we at the time of training applied talents, we should fully make theory combined with practice, and social synchronization.

A shortage of good teachers. Have a good teacher. The training of talents in universities and colleges can be improved further. But the quality team match, there are a lot of contradictions. But there are two big problem. One is that the recruitment of choose and employ persons, we take education so seriously. Not, don't let the teaching. So, there are certain advantages, there are also many shortcomings. Due to the common teacher, Dr Are theory very well. But the practice ability, is very weak. Make the students' practical ability, is not so high. If their own lack of experience, then makes taught students, is some deviation from knowledge system. Also can't achieve satisfactory results. And on the other hand. Is that many colleges and universities to narrow, the gap between the old undergraduate, to education, many teachers own degree increased, but the ability of practice will be relatively reduced. This also leads to the students' practical ability is weak.

\section{Newly built undergraduate course colleges and universities in transition in developing talent training method}

Build education, morality education system, and the top design highlight the people-oriented culture idea.University education, not only is to cultivate talents, to cultivate have a variety of quality talents, has a sound personality, at the same time has the noble moral character. The various training, after entering the society, makes the training of talents with ability to afford social pressure. When we were in the cultivation of talent development, also want to pay attention to the local economy and social demand as the main goal of developing our economy. Don't just blindly pursue economic. Want to notice with the student as this, to cultivate the students' sense of social responsibility at the same time, the sense of justice, sound personality, positive attitude, and so on. But also to cultivate students pay attention to the connotation, rich innovation spirit. With innovative spirit one aspect of this is very important. But also more should pay attention to the 
students' practical ability. From the aspects of education, curriculum embodies this goal, education fuses in together, pay attention to the cultivation of teachers, reform and construction in many aspects, develop a diversified talents. Makes the student's overall quality, ascend to a new level. Let more successful transformation, training scheme with their characteristics.

Adapt to the need of the society and industry, optimize the curriculum system setting. Newly built undergraduate course colleges and universities in the process of development, should be firstly optimize the curriculum system structure. According to the need of applied talents construction of all kinds of talents, also want to use the structure of high quality. After the adjustment of the professional structure, let's get weaving between traditional and modern subject. In this way, our starting point will be very high, conditions will be better. After all aspects of the conditions get better, then we can get good quality talents effectively. Can meet the needs of local economic, also can promote the development of the industry, according to the demand of the society, mobilize the professional set direction. At the same time, we should continually optimize the curriculum system, and also to do reasonable science. In the process of the implementation of talent, cultivate a variety of applied talents. One is we should according to the actual of professional targeted, selective set the base module, also want to, through the base set up courses with practical use. Second, we can adhere to the basic teaching as the teaching of professional service, design different courses, public courses can be hierarchical teaching, also can satisfy need not degree course modules. According to students' interests and the trend of future development, make the space of the students have a higher development. Also want to build and do supplement each other between the theoretical teaching system. Various layers of progressive, efforts to improve our professional. The students before entering the social various aspects ability improved.

Combined with production and education technology applied talents cultivation mode. Transformation in the newly-built universities pay attention to the development of applied talents, and enterprise cooperation should be enhanced. Comprehensive and deep, there are many forms and pragmatic spirit of cooperation. Needs not only scientific research, but also service, more should pay attention to education. Together to achieve innovation. We need to gradually develop and use all kinds of pattern, the reform of the cultivating applied talents. This can and sign the employment contract, let all the resource sharing, by conducting professional construction, but also has the talent training, we must pay attention to the construction of practice base, realize the perfect combination of enterprise and the school. Made good to determine the deepening school-running mode, applied talents. Is also very important to promote the depth of the cooperation between colleges.

\section{Conclusion}

Newly built undergraduate talent training is critical in the transformation and development in colleges and universities, it not only can effectively improve the students' practical ability, still can make students become applied talents. In the process of talent training, must be combined with the actual situation, to make a different analysis on different students, and to continue to deepen reform of education system, only in this way the cultivation of students' comprehensive abilities can be fully.

\section{Reference}

[1] guang-lin yuan. Integration of disciplines: the newly built undergraduate course colleges and universities discipline construction strategy [J]. Journal of university education management. 2016 (02) : 12-14.

[2] Liu Liangxun. The newly built undergraduate course colleges and universities "two evaluation" and the application of ISO quality management system [J]. Journal of yulin university journal. 2011 (01) : 126-127.

[3] Fu E. The problems existing in the newly built undergraduate course colleges and universities discipline construction and thinking [J]. Journal of nanyang institute of technology. 2009 (02) : 101-103. 